Jurnal_ep, Vol. 8 No. 1, Maret 2018

\title{
PENGARUH ASESMEN PORTOFOLIO TERHADAP KEMANDIRIAN DAN MINAT MENULIS AKSARA BALI PADA SISWA KELAS VIII DI SMP N 2 BANJAR
}

\author{
Oleh \\ Md Suryadana ${ }^{1}$, Md Sri Mertasari,2, , Ni Kt Widiartini3,, \\ 1,2,3 Program Studi Penelitian dan Evaluasi Pendidikan, Program Pasca Sarjana \\ Universitas Pendidikan Ganesha \\ Singaraja, Indonesia \\ e-mail : suryadana255@gmail.com, srimertasari@yahoo.co.id, \\ ketut.widiartini\}@pasca.undiksha.ac.id
}

\begin{abstract}
Abstrak
Penelitian ini bertujuan untuk mengetahui pengaruh asesmen portofolio terhadap kemandirian dan minat menulis Aksara Bali pada siswa kelas VIII di SMP N 2 Banjar. Penelitian ini tergolong dalam quasi eksperiment dengan jenis post-tests only control group design. Populasi penelitian ini berasal dari kelas VIII dengan jumlah 9 kelas. Penentuan sampel dilakukan dengan teknik random sampling. Kesembilan kelas yang sudah dinyatakan setara melalui uji $F$ diundi untuk mendapatkan sampel. Sampel penelitian ini menggunkan 2 kelas, yaitu kelas VIII 1 sebagai kelas eksperimen dan VIII 5 sebagai kelas kontrol. Instrumen penelitian ini berupa kuesioner kemandirian menulis Aksara Bali dan kuesioner minat menulis Aksara Bali. Analisis yang digunakan adalah MANOVA. Hasil penelitian menemukan bahwa, 1) terdapat perbedaan kemandirian dan minat menulis Aksara Bali antara siswa yang mengikuti pembelajaran dengan asesmen portofolio dengan siswa yang mengikuti asesmen uraian; 2) Terdapat perbedaan kemandirian menulis Aksara Bali antara siswa yang mengikuti pembelajaran dengan asesmen portofolio dengan siswa yang mengikuti asesmen uraian; 3) Terdapat perbedaan minat menulis Aksara Bali antara siswa yang mengikuti pembelajaran dengan asesmen portofolio dengan siswa yang mengikuti asesmen uraian. Jadi, dapat disimpulkan bahwa asesmen portofolio berpengaruh positif terhadap kemandirian dan minat menulis Aksara Bali siswa, asesmen portofolio berpengaruh terhadap kemandirian menulis Aksara Bali siswa, dan asesmen portofolio berpengaruh positif terhadap minat menulis Aksara Bali siswa.
\end{abstract}

Kata kunci : asesmen portofolio, kemandirian, minat

\begin{abstract}
This study aims at finding out the effects of portfolio assessment on the independent and the interest in writing Balinese's alphabet toward VIII grade students in SMP N 2 Banjar. This study belongs to quasi experiment with post-tests only control group design type. The populations of this study are 9 classes from VIII grade students. The sample selected by using random sampling technique. All nine classes' students which were considered equivalent by using $\mathrm{F}$ test were voted as samples. 2 classes that voted were used as samples in this study were class VIII 1 as an experiment class and class VIII 5 as controlled class. The instrument used in this study are Balinese's alphabet writing independent questionnaire and Balinese' alphabet writing interest questionnaire. This study analyzed using MANOVA. The result of this study showed that 1) There are differences between independent and interest in writing Balinese's alphabet between students that are assessed by portfolio assessment and description assessment. 2) There are differences in Balinese's alphabet writing independent between students that are assessed by portfolio assessment and description assessment. 3) There are differences in Balinese's alphabet writing interest between students that are assessed by portfolio assessment and description assessment. It can be concluded that portfolio assessment gives good influences toward student's independent and interest in writing Balinese's alphabet, portfolio assessment gives good influences toward student's independent in
\end{abstract}


writing Balinese's alphabet, portfolio assessment gives good influences toward student's interest in writing Balinese's alphabet

Keywords : portfolio assessment, independence, interest

\section{PENDAHULUAN}

Bahasa Bali adalah salah satu mata pelajaran muatan lokal yang ada pada jenjang sekolah menengah pertama. Salah satu keterampilan dalam pembelajaran Bahasa Bali adalah menulis dengan Aksara Bali. Menulis dengan Aksara Bali merupakan salah satu Kompetensi Dasar yang tertuang dalam Silabus Pembelajaran Bahasa Bali dengan Standar Kompetensi memahami penulisan warga aksara, tengenan dan pasang Aksara Bali. Kompetensi Dasar menulis tengenan Aksara Bali dan Indikator dapat menyebutkan macam-macam tengenan, dapat menuliskan bentuk-bentuk tengenan, dapat membedakan penggunaan masing-masing tengenan, dan dapat menggunakan macam-macam tengenan tersebut dalam contoh kata.

Dewasa ini, bahasa Bali justru dikeluhkan oleh peserta didik. Peserta didik menganggap bahasa Bali sebagai bahasa yang kuno dan sangat sulit untuk dipahami dan dibahasakan melalui tulisan maupun lisan. Peserta didik tidak tertarik lagi terhadap pelajaran bahasa Bali. Seringkali pada proses pembelajaran bahasa Bali, peserta didik hanya sekedar belajar, tanpa memahami apa tujuan dari pembelajaran bahasa Bali tersebut.

Pendekatan pembelajaran bukan satu-satunya aspek yang mendukung hasil belajar yang baik dalam keterampilan menulis, tetapi ada faktor lain yang sangat mendukung hasil belajar peserta didik. Salah satunya adalah penilaian yang digunakan oleh seorang pendidik untuk mengetahui sejauhmana pemahaman peserta didik pada materi tersebut. Dengan penilaian yang tepat, maka pendidik juga akan mudah untuk memberikan kesimpulan terhadap proses dan hasil belajar peserta didik. Semua aktivitas dan hasil belajar dalam menulis Aksara Bali perlu diketahui tingkat ketercapaiannya.

Komponen pembelajaran yang dapat memberikan informasi tentang tingkat ketercapaian pada pembelajaran menulis Aksara Bali yang dilakukan peserta didik adalah penilaian. Penilaian merupakan proses pemberian nilai angka, khususnya nilai ketercapaian belajar peserta didik secara menyeluruh. Semua komponen belajar baik pada aspek hasil maupun proses perlu diberi nilai. Hal ini dimaksudkan untuk melihat dan mengetahui seberapa besar peserta didik telah mengikuti dan melakukan proses belajar dalam mencapai tujuan dan kemampuannya sendiri sebagai hasil belajar.

Selama ini, dalam pembelajaran bahasa Bali khusnya menulis Aksara Bali, penilaian hanya menggunakan ulangan yang dilaksanakan pada akhir penyampaian materi sesuai dengan RPP yang telah dibuat. Bahkan, penilaan untuk beberapa materi ajar dilakukan dalam tes sekaligus.

Dalam perspektif tersebut maka penggunaan asesmen otentik untuk pembelajaran bahasa Bali sangat diperlukan. Penilaian yang sedang digalakkan dalam pendidikan Indonesia dewasa ini adalah penilaian autentik atau asesmen autentik. Asesmen otentik adalah proses penilaian siswa dengan membawa pembelajaran pada ranah autentik yang kontekstual. Asesmen autentik terdiri dari beberapa jenis, salah satunya adalah asesmen portofolio. Asesmen portofolio adalah asesmen yang paling lengap. Pada asesmen portofolio terapat penilaian kinerja, proses, produk, dan evaluasi diri.

Untuk membuat pembelajaran bahasa Bali menjadi pembelajaran yang bermakna, maka penilaian atau asesmen yang digunakan adalah asesmen portofolio. Marhaeni (2011) mendefinisikan asesmen portofolio adalah suatu prosedur pengumpulan informasi mengenai perkembangan dan kemampuan siswa melalui portofolionya, dimana pengumpulan informasi tersebut dilakukan secara formal dengan menggunakan kriteria tertentu, untuk tujuan pengambilan keputusan terhadap status siswa.

Dalam sebuah pembelajaran, ada beberapa faktor yang tidak kalah penting untuk menentukan keberhasilan siswa 
dalam belajar, khusunya faktor yang berasal dari dalam diri siswa itu sendiri. Faktor yang berasal dari dalam diri siswa yang mampu mendukung keberhasilan siswa dalam belajar adalah kemandirian dan minat.

Kemandirian belajar adalah belajar mandiri, tidak menggantungkan diri kepada orang lain, siswa dituntut untuk memiliki keaktifan dan inisiatif sendiri dalam belajar, bersikap, berbangsa maupun bernegara (Ahmadi dan Uhbiyati, 1990:13).

Anak yang mempunyai kemandirian belajar dapat dilihat dari kegiatan belajarnya. Dia tidak perlu disuruh bila belajar dan kegiatan belajar dilaksanakan atas inisiatif dirinya sendiri. Dengan adanya sikap kemandirian dalam diri siswa, maka secara otomatis siswa akan belajar dan berusaha sendiri untuk menguasi materi pelajaran yang diajarkan tanpa disuruh oleh guru. Apalagi dewasa ini pembelajaran tidak hanya bisa dilakukan di sekolah. Dimanapun kita bisa belajar dengan memanfaatkan akses teknologi sudah canggih. Sumber belajar bisa kita akses melalui internet, bukubuku, maupun sumber daya manusia lainnya.

Disamping kemandirian belajar, minat belajar juga menjadi faktor yang harus diperhatikan dalam menentukan keberhasilan belajar siswa. Minat menurut Wikel (1999:212) adalah kecenderungan subyek yang menetap untuk merasa tertarik pada bidang studi atau pokok bahasan tertentu dan merasa senang mempelajari materi pelajaran. Menurut Slameto, (2003:2) minat adalah suatu rasa lebih suka dan rasa ketertarikan pada suatu alat atau aktifitas tanpa ada yang menyuruh.

Minat belajar pada dasarnya adalah penerimaan akan adanya suatu hubungan antara diri sendiri dengan diluar diri sendiri. Ketika siswa sudah memiliki minat dalam belajar bahasa Bali, maka ia akan menerima materi yang telah disampaikan oleh gurunya dan mencari berbagai litelatur pelajaran tanpa adanya paksaan dari siapapun. Minat juga merupakan sumber motivasi yang mendorong seseorang untuk melakukan apa yang ingin dilakukan ketika bebas memilih. Ketika seseorang menilai bahwa sesuatu akan bermanfaat, maka akan menjadi berminat, kemudian hal tersebut akan mendatangkan kepuasan.
Ketika siswa memiliki kemandirian dan mint belajar menulis Aksara Bali yang tinggi, maka proses pembelajaran siswa akan semakin cepat. Dorongan internal berupa kemandirian dan minat sangat penting dalam belajar. Ketika kemandirian dan minat siswa tinggi, perlu asesmen yang mumpuni untuk mewadahi hal tersebut. Asesmen portofolio adalah asesmen yang sangat komplit. Dalam asesmen portofolio mencakup asepek kognitif, afektif, dan psikomor dan memiliki aspek penting yaitu sampel karya siswa, penilaian yang terbuka, dan evaluasi diri.

Tujuan penelitian ini sejalan dengan rumusan masalah yang telah dipaparkan di atas, yaitu 1) Untuk mengetahi perbedaan kemandirian dan minat menulis Aksara Bali antara siswa yang mengikuti pembelajaran dengan asesmen portofolio dan siswa yang mengikuti pembelajaran dengan asesmen formatif bentuk uraian. 2) Untuk mengetahui perbedaan kemandirian menulis Aksara Bali antara siswa yang mengikuti pembelajaran dengan asesmen portofolio dan siswa yang mengikuti pembelajaran dengan asesmen formatif bentuk uraian. 3) Untuk mengetahi perbedaan minat menulis Aksara Bali antara siswa yang mengikuti pembelajaran dengan asesmen portofolio dan siswa yang mengikuti pembelajaran dengan asesmen formatif bentuk uraian.

\section{METODE}

Pada penelitian ini metode yang digunakan adalah metode eksperimen semu atau quasi experimental research. Disebut penelitian eksperimen semu karena tidak semua variabel (gejala yang muncul) dan kondisi eksperimen dalam penelitian ini dapat diatur dan dikontrol secara ketat. Dalam penelitian ini subjek dibagi menjadi 2 kelompok, yaitu kelas eksperimen dan kelas kontrol. Pada kelas eksperimen diberi perlakuan dengan menggunakan asesmen portofolio. Pada kelas kontrol dibrikan asesmen formatif bentuk uraian. Populasi penelitian ini berasal dari kelas VIII. Di SMP $\mathrm{N} 2$ Banjar terdapat 9 kelas untuk siswa kelas VIII. Kelas 8 yang ada di SMP N 2 Banjar ,yaitu kelas VIII 1, VIII 2, VIII 3, VIII 4, VIII 5 yang mengikuti kelas pagi dan kelas VIII 6, VIII 7, VIII 8, VIII 9 yang mengikuti 
kelas sore. Masing-masing kelas terdiri dari 40 orang siswa.

Untuk mengetahui kesetaraan kelas populasi, perlu dilakukan uji kesetaraan. Uji kesetaraan yang digunakan dalam penelitian ini adalah uji homogenitas varians yaitu analisis varian (ANAVA) satu jalan. Pengujian ini dilakukan untuk mengetahui apakah kelima kelas tersebut memiliki kemampuan yang setara atau tidak. Adapun yang menjadi dasar uji kesetaraan adalah nilai menulis Aksara Bali siswa tahun ajaran 2016/2017.

Berdasarkan karakteristik populasi, teknik pengambilan sampel yang digunakan adalah random sampling, yaitu teknik pengambilan sampel dari populasi dilakukan secara acak tanpa memperhatikan strata yang ada dalam populasi itu terhadap pasangan-pasangan kelas yang setara (Sugiyono, 2009). Pemilihan dan penetapan kelompok eksperimen dilakukan dengan teknik random sampling terhadap pasangan kelas setara yang terpilih sebagai sampel. $\mathrm{Hal}$ ini dilakukan mengingat kelas telah terbentuk sebelumnya dan tidak memungkinkan untuk mengubah kelas yang sudah ada. Pemilihan kelas eksperimen dan kontrol dilakukan dengan pengundian. Kelas pertama yang keluar dalam undian dipakai sebagai kelas ekpserimen dan kelas kedua yang keluar dalam undian dipakai sebgai kelas kontrol. Berdasarkan hasil pengundian diperoleh sampel, yaitu kelas VIII 1 sebagai kelas eksperimen dan kelas VIII 5 sebagai kelas kontrol.

Instrumen dalam penelitian ini berupa kuisioner. Kuesioner yang digunakan ada dua, yaitu kuesioner kemandirian menulis Aksara Bali dan kuesioner minat menulis Aksara Bali. Sebelum digunakan, kuesioner harus diuji terlebih dahulu. Uji judges dengan model gregory menunjukkan kedua istrumen kuesioner memiliki validitas yang tinggi. pada kuesioner minat menulis Aksara Bali terdapat beberapa tambahan pernyataan yang disarankan oleh judges. Instrumen tersebut kemudian diuji coba lapangan untuk mencari validitas dan reliabilitasnya. Semua butir pernyataan pada kedua kuesioner valid dan kedua kuesioner reliabel dengan nilai reliabilitas kuesioner kemandirian sebesar $\mathrm{R}=0,998$ dan kuesioner minat $\mathrm{R}=0,980$ yang tergolong dalam kategori sangat tinggi. Teknik analisis data yang digunakan adalah statistik deskriptif dengan analisis menggunakan MANOVA.

\section{HASIL PENELITIAN}

Berdasarkan

rata-rata skor kemandirian menulis Aksara Bali siswa yang mengikuti pembelajaran dengan asesmen portofolio yaitu 242,5, maka kemandirian menulis Aksara Bali siswa yag mengikuti pembelajaran dengan asesmen portofolio termasuk kategori sangat tinggi.

Berdasarkan rata-rata skor minat menulis Aksara Bali siswa yang mengikuti pembelajaran dengan asesmen portofolio yaitu 210,6,5, maka minat menulis Aksara Bali siswa yang mengikuti pembelajaran dengan asesmen portofolio termasuk kategori sangat tinggi.

Berdasarkan rata-rata skor kemandirian menulis Aksara Bali siswa yang mengikuti pembelajaran dengan asesmen uraian 214,75, maka kemandirian menulis Aksara Bali siswa yag mengikuti pembelajaran dengan asesmen uraian termasuk kategori tinggi.

Berdasarkan rata-rata skor minat menulis Aksara Bali siswa yang mengikuti pembelajaran dengan asesmen portofolio yaitu 184,625, maka minat menulis Aksara Bali siswa yang mengikuti pembelajaran dengan asesmen uraian termasuk kategori tinggi.

Sebagai syarat agar dapat dilakukan uji hipotesis dengan MANOVA, terlebih dahulu dilakukan uji persyaratan. Uji persyaratan tersebut adalah uji normalitas, uji homogenitas varians, uji homogenitas varinas/kovarians, dan uji kolinearitas.

Pengujian normalitas sebaran data ke empat kelompok tersebut dilakukan dengan menggunakan spss menerapkan teknik Kolmogorov-Smirnov. Kriteria pengujian, terima $\mathrm{H}_{\mathrm{o}}$ jika nilai sig pada tabel Kolmogorov-Smirnov lebih besar dari sig ${ }_{\alpha}$ yang ditetapkan yaitu 0,05 yang berarti data berdistribusi normal dan tolak $\mathrm{H}_{\mathrm{o}}$ jika nilai sig pada tabel Kolmogorov-Smirnov lebih kecil dari $\operatorname{sig}_{\alpha}$ yang ditetapkan yaitu 0,05 yang berarti data tidak berdistribusi normal. Perhitungan uji normalitas menggunakan spss dengan teknik Kolmogorov-Smirnov menunjukkan bahwa nilai sig. pada tabel 
Kolmogorov-Smirnov lebih besar dari $\alpha$ yang ditetapkan yaitu 0,05 untuk semua kelompok. Ini berarti $\mathrm{H}_{\mathrm{o}}$ diterima, maka ke empat kelompok data berdistribusi normal.

Uji homogenitas varians pada data penelitian ini dilakukan pada empat kelompok data, yaitu 1) Data kemandirian menulis Aksara Bali pada siswa yang mengikuti asesmen portofolio (A1Y1); 2) Data minat menulis Aksara Bali siswa yang mengikuti asesmen portofolio (A1Y2); 3) Data kemandirian menulis Aksara Bali pada siswa yang mengikuti asesmen uraian (A2Y1); 4) Data minat menulis Aksara Bali siswa yang mengikuti asesmen uraian (A2Y2). Dari hasil perhitungan, diperoleh nilai sig. lebih besar dari harga a 0,05 yang berarti hipotesis nol ditolak. Dengan demikian dapat disimpulkan ke empat data adalah homogen.
Uji homogenitas varians/kovarian dilakukan dengan menggunakan SPSS for Windows 16. Hasil pengujian mendapatakan nilai siginfikansi sebesar 0,389 yang berarti lebih besar dari taraf signifikansi 0,05. Maka dari itu, matrik varian dank ovarian adlah homogen.

Uji kolinearitas yang telah dilakukan mendapatkan hasil $\boldsymbol{r}_{A_{1} A_{2}}=0,889$ dimana lebih kecil dari $\boldsymbol{r}_{\text {tabel }}=1,79$. Dengan demikian, sesama variabel terikat tidak terjadi korelasi yang kuat.

Berdasarkan hasil uji normalitas, uji homogenitas varians, uji homogenitas varinas/kovarians, dan uji kolinearitas, dapat disimpulkan bahwa data dari semua kelompok berasal dari populasi yang berdistribusi normal dan mempunyai varians yang homogen. Oleh karena itu, uji hipotesis dengan MANOVA dapat dilakukan.

Tabel 1

\section{Multivariat Test}

\begin{tabular}{lccccc}
\hline Effect & Value & F & dk Hipotesis & dk eror & Sig. \\
\hline Intercept Pillai's Trace & 0,999 & $2,762 \mathrm{E} 4^{\mathrm{a}}$ & 2,000 & 77,000 & 0,000 \\
Wilks' lambda & 0,001 & $2,762 \mathrm{E} 4^{\mathrm{a}}$ & 2,000 & 77,000 & 0,000 \\
Hotelling's trace & 717,433 & $2,762 \mathrm{E}^{\mathrm{a}}$ & 2,000 & 77,000 & 0,000 \\
$\begin{array}{l}\text { Roy's Largest } \\
\text { Root }\end{array}$ & 717,433 & $2,762 \mathrm{E} 4^{\mathrm{a}}$ & 2,000 & 77,000 & 0,000 \\
\hline Asesmen Pillai's Trace & 0,762 & $1,232 \mathrm{E} 2^{\mathrm{a}}$ & 2,000 & 77,000 & 0,000 \\
Wilks' Lambda & 0,238 & $1,232 \mathrm{E} 2^{\mathrm{a}}$ & 2,000 & 77,000 & 0,000 \\
Hotelling's trace & 3,201 & $1,232 \mathrm{E} 2^{\mathrm{a}}$ & 2,000 & 77,000 & 0,000 \\
Roy's Largest & 3,201 & $1,232 \mathrm{E} 2^{\mathrm{a}}$ & 2,000 & 77,000 & 0,000 \\
Root & & &
\end{tabular}

Tabel 2

Tests of Between Subject Effects

\begin{tabular}{llrrrrrr}
\hline Source & Variabel terikat & $\begin{array}{r}\text { Type III Sum } \\
\text { of Squares }\end{array}$ & dk & Mean Square & F & Sig. \\
\hline Asesmen & Kemandirian & 18972,800 & 1 & 18972,800 & 200,352 & 0,000 \\
& Minat & 13520,000 & 1 & 13520,000 & 200,487 & 0,000 \\
\hline
\end{tabular}

Hipotesis pertama yang diuji pada penelitian perbedaan kemandirian dan minat menulis Aksara Bali antara siswa yang mengikuti pembelajaran formatif bentuk portofolio dan siswa yang mengikuti pembelajaran dengan asesmen formatif bentuk uraian. Hasil perhitungan MANOVA pada tabel menunjukkan bahwa nilai Sig $_{\text {hitung }}$ $=0,000$ dan nilai $\operatorname{Sig}_{\alpha}=0,05$. Karena Sighitung $>$ Sig ${ }_{\alpha}$ berarti $\mathrm{H}_{\circ}$ ditolak dan $\mathrm{H}_{1}$ diterima. Dapat disimpulkan bahwa terdapat perbedaan kemandirian dan minat menulis Aksara Bali antara siswa yang mengikuti pembelajaran formatif bentuk portofolio dan 
siswa yang mengikuti pembelajaran dengan asesmen formatif bentuk uraian.

Hipotesis kedua yang diuji dalam penelitian ini adalah kemandirian menulis Aksara Bali antara siswa yang mengikuti pembelajaran formatif bentuk portofolio dan siswa yang mengikuti pembelajaran dengan asesmen formatif bentuk uraian. Hasil perhitungan MANOVA pada tabel menunjukkan bahwa nilai Sig $_{\text {hitung }}=0,000$ dan nilai Sig $=0,05$. Karena Sig hitung $>$ Sig $_{\alpha}$ berarti $\mathrm{H}_{\circ}$ ditolak dan $\mathrm{H}_{1}$ diterima. Dapat disimpulkan bahwa terdapat perbedaan kemandirian menulis Aksara Bali antara siswa yang mengikuti pembelajaran formatif bentuk portofolio dan siswa yang mengikuti pembelajaran dengan asesmen formatif bentuk uraian.

Hipotesis ketiga yang diuji dalam penelitian ini adalah minat menulis Aksara Bali antara siswa yang mengikuti pembelajaran formatif bentuk portofolio dan siswa yang mengikuti pembelajaran dengan asesmen formatif bentuk uraian. Hasil perhitungan MANOVA pada tabel menunjukkan bahwa nilai Sig $_{\text {hitung }}=0,000$ dan nilai $\operatorname{Sig}_{\alpha}=0,05$. Karena Sighitung $>$ Sig $_{\text {alfa, }}$ berarti $\mathrm{H}_{\circ}$ ditolak dan $\mathrm{H}_{1}$ diterima. Dapat disimpulkan bahwa terdapat perbedaan minat menulis Aksara Bali antara siswa yang mengikuti pembelajaran formatif bentuk portofolio dan siswa yang mengikuti pembelajaran dengan asesmen formatif bentuk uraian.

\section{PEMBAHASAN}

Hasil uji hipotesis pertama diperoleh hasil bahwa terdapat perbedaan kemandirian dan minat menulis Aksara Bali antara siswa yang mengikuti pembelajaran formatif bentuk portofolio dan siswa yang mengikuti pembelajaran dengan asesmen formatif bentuk uraian.

Pada kelas eksperimen, diperoleh data skor kemandirian menulis Aksara Bali sebanyak 30\% siswa memperoleh skor sekitar rata-rata, sebanyak $35 \%$ siswa memperoleh skor dibawah rata-rata, dan $35 \%$ siswa memperoleh skor di atas ratarata. Pada kelas kontrol, diperoleh skor kemandirian menulis Aksara Bali sebanyak $25 \%$ siswa memperoleh skor sekitar ratarata, sebanyak $62,5 \%$ siswa memperoleh skor dibawah rata-rata, dan $12,5 \%$ siswa memperoleh skor di atas rata-rata.

Perolehan persentase skor tersebut menunjukkan bahwa kemandirian menulis Aksara Bali pada kelas eksperimen lebih tinggi dari kelas kontrol. Persentase selisih skor sekitar rata-rata $5 \%$, selisih skor dibawah rata-rata $27,5 \%$, dan selisih skor di atas rata-rata $22,5 \%$.

Pada kelas esksperimen, diperoleh skor minat menulis Aksra Bali sebanyak $37,5 \%$ siswa memperoleh skor sekitar ratarata, sebanyak $37,5 \%$ siswa memperoleh skor dibawah rata-rata, dan $25 \%$ siswa memperoleh skor di atas rata-rata. Pada kelas kontrol, diperoleh skor minat menulis Aksara Bali sebanyak $27,5 \%$ siswa memperoleh skor sekitar rata-rata, sebanyak $60 \%$ siswa memperoleh skor dibawah ratarata, dan $12,5 \%$ siswa memperoleh skor di atas rata-rata.

Perolehan persentase skor tersebut menunjukkan bahwa minat menulis Aksara Bali pada kelas eksperimen lebih tinggi dari kelas kontrol. Persentase selisih skor sekitar rata-rata $10 \%$, selisih skor dibawah rata-rata $22,5 \%$, dan selisih skor di atas rata-rata $12,5 \%$.

Asesmen portofolio bertujuan sebagai alat formatif maupun sumatif. Menurut Arifin (2010) portofolio sebagai alat formatif digunakan untuk memantau kemajuan siswa dari hari-kehari dan untuk mendoroong siswa dalam merefleksi pembelajaran mereka sendiri. Portofolio seperti ini difokuskan pada proses perkembangan siswa dan digunakan untuk tujuan formatif diagnostik. Sedangkan sebagai alat sumatif, portofolio dapat digunakan untuk mengisi angka rapor siswa pada akhir tahun pelajaran, yang menunjukan prestasi siswa dalam mata pelajaran Bahasa Bali. Disampaing itu, tujuan portofolio adalah untuk memberikan informasi tentang perkembangan siswa secara lengkap dengan dukungan data dan dokumen yang akurat.

Tingkat kemandirian dan minat menulis Aksara Bali siswa yang mengikuti pembelajaran dengan asesmen portofolio lebih tinggi dibandingkan dengan tingkat kemandirian dan minat siswa yang mengikuti pembelajaran dengan asesmen uraian 
dikarenakan faktor asesmen portofolio itu sendiri.

Pertama, asesmen portofolio dilakukan secara holistik salama proses pembelajaran, artinya penilaian ini tidak hanya menilai hasil akhir, namum proses siswa dalam menuju hasil akhir selama proses pembelajaran juga menjadi bagian penting dalam asesmen ini. Arifin (2010) bahkan mengatakan bahwa penilaian portofolio menilai 3 ranah, yaitu kognitif, afektif, dan psikomotor secara holistic. Penilaian yang lebih mengutamakan proses namun juga tidak mengesampingkan hasil akhir seperti asesmen portofolio mampu menumbuhkan minat tau keinginan untuk melajar menulis Aksara Bali yang berimbas positif terhadap munculnya kemandirian dalam belajar menulis Aksara Bali. Hal ini dikarenakan setiap usaha yang dilakukan siswa itu sendiri dalam belajar akan dinilai oleh guru. Tidak ada usaha belajar yang tidak dinilai oleh guru.

Berbeda dengan asesmen uraian yang biasa digunakan oleh guru. Penilain hanya dilakukan pada akhir pertemuan. Kadang kala penilaian beberapa materi dijadikan satu. Jerih payah siswa dalam proses pembelajaran tidak diperhitungkan dalam asesmen uraian. Hal ini dapat mengurangi minat siswa dalam belajar sehingga kemandirian siswa dalam belajar menulis Aksara Bali menurun. Siswa akan kecewa karena usaha mereka selama proses pembelajaran tidak dihargai.

Kedua, asesmen portofolio menurut Dantes (2008); Marhaeni (2005), mengandung tiga elemen pokok yaitu: (1) sampel karya siswa, (2) kriteria penilaian yang jelas dan terbuka, dan (3) evaluasi diri. Ketiga elemen ini mampu menumbuhkan kemandirian siswa dalam belajar menulis Aksara Bali. Dengan adanya kriteria penilaian yang jelas, maka siswa akan semangat untuk untuk belajar. Mereka tahu bagaimana guru akan menilai dalam pembelajaran menulis Aksara Bali. Jadi, keinginan siswa untu belajar menulis Aksara Bali pasti tumbuh. Semakin tinggi keinginan siswa untuk belajar, maka kemandirian belajarnya juga pasti meningkat. Siswa akan berusaha untuk belajar sendiri agar mampu mendapatkan nilai dari penilaian yang telah disampaikan.
Sampel karya siswa merupakan elemen yang sangat penting dalam penialian, khususnya penilian portofolio. Dengan adanya sampel karya siswa, maka siswa akan mengetahui bagaimana perkembangannya dalam belajar menulis Aksara Bali dari awal sampai akhir. Segala sesuatu yang siswa kerjakan terekam dalam sampel karya siswa. Siswa tidak akan merasa dibohongi dalam penilaian karena mereka bisa melihat sendiri pekembangannya dalam belajar. Inilah yang memicu ketertarikan siswa untuk belajar secara mandiri. Evaluasi diri merupkan elemen yang penting dalam penilaian asesmen portofolio. Siswa secara mandiri harus menilai kekurangan dan kelebihannya dalam belajar menulis Aksara Bali. Melalui evaluasi diri ini, minat dan kemandirian siswa dalam belajar menulis Aksara Bali akan terus tumbuh. Mereka diberikan kesempatan untuk menilai sejauhmana keberhasilannya dalam belajar menulis Aksara Bali. Dengan demikian, kekurangan yang siswa miliki dalam belajar Aksara Bali menjadi pemicu untuk belajar secara mandiri untuk meminimalisir kekurangannya.

Pada kelas eksperimen, kemandirian dan minat siswa dalam menulis Aksara Bali sangat nampak. Kesadaran belajar mandiri terlihat pada siswa sadar akan tugas dan kewajibannya sebagai pelajar yaitu belajar. Keinginan belajar siswa muncul tanpa paksaan, tanpa harus disuruh orang baik itu guru atau orang tua. Paham waktu dalam belajar dan paham dimana waktunya belajar. Bertanggung jawab pada tugas-tugas menulis Aksara Bali yang diberikan. Bentuk pertanggung jawaban adalah mengumpulkan tugas tepat waktu. Percaya diri akan kemampuan yang dimiliki. Kemampuan yang dimiliki digunakan untuk mengerjakan tuagas-tugas menulis Aksara Bali yang diberikan guru. Siswa menggunakan kemampuannya sendiri dalam mengerjakan tugas-tugas menulis Aksara Bali yang diberikan. Dapat mengambil keputusan yang baik dalam belajar. Mereka tahu sesuatu proses yang dilakukan dengan baik dan benar akan menghasilkan hasil yang maksimal untuk dirinya.

Minat menulis siswa sangat tampak pada kelas eksperimen. Mereka sangat 
senang dalam mengikuti pembelajaran menulis Aksara Bali. Mereka juga sangat aktif dalam bertanya dan menjawab. Tidak ada perasaan malu untuk bertanya ketika mereka belum paham dengan materi yang dijelaskan guru. Siswa lain juga bersemangat untuk menunjukkan kemampuannya dengan menjawab pertanyaan baik dari guru maupun pertanyaan dari temannya. Ketika guru menjelaskan materi, siswa fokus mendengarkan apa yang dijelaskan guru. Ketertarikan siswa juga akan Aksara Bali juga muncul. Salah satu siswa ikut dalam ektrakulikuler nyastra Bali setelah mengikuti pembelajaran dengan asesmen portofolio ini. Mereka mulai memperhatikan tulisantulisan berAksara Bali yang ada di lingkungan sekolah maupun di sekitar rumahnya seperti plang-plang instansi. Beberapa siswa berani mengomentari kesalahan-keslahan yang ada pada penulisan Aksara Bali pada plang papan nama instansi yang ada di sekitarnya.

Pada kelas kontrol yang
menggunakan asesmen uraian dalam pembelajaran menulis Aksara Bali tidak menunjukkan munculnya minat dan kemandirian siswa dalam menulis Aksara Bali. Siswa cenderung enggan untuk belajar menulis Aksara Bali. Mereka kurang merasa senng dalam belajar menulis Aksara Bali sehingga mereka cenderung sering bermain. Dalam mengerjakan tugas juga mereka kurang serius. Banyak siswa yang rebut dalam mengerjakan tugas. Ada juga siswa yang hanya sekedar mengerjkan tugas. Interaksi siswa dengan guru dikelas sangat kurang.

Hal ini juga didukung oleh hasil penelitian yang dilakukan oleh Chairunisa (2017) yang berjudul "Pemanfaatan Penilian Portofolio pada Mata Kuliah Evaluasi Pembelajaran Sejarah dalam Upaya Membangun Karakter Belajar mandiri dan Berkelanjutan". Hasil penelitian ini menunjukkan bahwa penilaian portofolio mampu memenuhi prinsip-prinsip kegiatan belajar mandiri. Mahasiswa diajak berdiskusi untuk menentukan tujuan pembelajaran, kriteria dan jenis kegiatan pembelajaran . Penilaian dilakukan berdasarkan kriteria yang telah ditentukan sebelumnya. Mahasiswa diberi kesempatan untuk melakukan self-assessment dan merefleksi karya mereka sendiri. Dosen dan mahasiswa berdiskusi mengenai pengalam belajar dan kelemahan serta keunggulan yang mereka miliki. Dengan motivasi dan minat belajar yang tinggi akan membentuk keinginan yang kuat untuk terus belajar dan mengembangkan diri secara berkelanjutan.

Hasil penelitian yang dilakukan oleh Agus (2013) yang berjudul "Pengaruh Optimalisasi Asesmen Diri terhadapa Kemampuan Menulis Bahasa Inggris ditinjau dari Minat Siswa pada Kelas V di Gugus II Kecamatan Gianyar" juga turut memperkuat penelitian ini. Hasil penelitiannya menunjukkan adanya pengaruh interaksi antara jenis asesmen dan minat siswa terhadap kemampuan menulis Bahasa Inggris. Hasil penelitian ini menunjukkan bahwa asesmen dan minat memiliki adanya interaksi, dalam hal ini adalah asesmen portofolio dengan minat menulis Aksara Bali siswa.

Berdasarkan uraian di atas, dapat disimpulkan bahwa terdapat perbedaan kemandirian dan minat menulis Aksara Bali antara siswa yang mengikuti pembelajaran dengan asesmen portofolio dengan siswa yang mengikuti pembelajaran menulis Aksara Bali dengan asesmen uraian. Siswa yang mengikuti pembelajaran menulis Aksara Bali dengan asesmen portofolio (kelas eksperimen) memiliki kemandirian dan minat menulis Aksara Bali lebih tinggi dari siswa yang mengikuti pembelajaran menulis Aksara Bali dengan asesmen uraian (kelas kontrol). Melihat kemandirian dan minat menulis Aksara Bali siswa yang mengikuti pembelajaran dengan asesmen portofolio lebih tinggi, maka asesmen portofolio layak dipilih maupun digunakan sebagai asesmen dalam pembelajaran menulis Aksara Bali.

Uji hipotesis kedua, menyatakan terdapat perbedaan kemandirian menulis Aksara Bali antara siswa yang mengikuti pembelajaran formatif bentuk portofolio dan siswa yang mengikuti pembelajaran dengan asesmen formatif bentuk uraian.

Sampel karya siswa merupakan elemen yang sangat penting dalam penialian, khususnya penilian portofolio. Dengan adanya sampel karya siswa, maka siswa akan mengetahui bagaimana 
perkembangannya dalam belajar menulis Aksara Bali dari awal sampai akhir. Segala sesuatu yang siswa kerjakan terekam dalam sampel karya siswa. Siswa tidak akan merasa dibohongi dalam penilaian karena mereka bisa melihat sendiri pekembangannya dalam belajar. Inilah yang memicu ketertarikan siswa untuk belajar secara mandiri.

Kriteria penilian yang jelas sangat dibutuhkan dalam melakukan sebuah penilaian. Dengan adanya kriteria penilaian yang jelas mereka tahu bagaimana sistem dan kriteria guru dalam menilai pada pembelajaran menulis Aksara Bali. dengan demikian, siswa pasti berupaya untuk menunjukkan kemampuannya dalam segala penilaian yang dilakukan. Siswa akan berusaha untuk belajar sendiri agar mampu mendapatkan nilai dari penilaian yang telah disampaikan.

Evaluasi diri merupkan elemen yang tidak kalah penting dalam penilaian asesmen portofolio. Siswa secara mandiri harus menilai kekurangan dan kelebihannya dalam belajar menulis Aksara Bali. Melalui evaluasi diri ini, kemandirian siswa dalam belajar menulis Aksara Bali semkin tumbuh. Mereka diberikan kesempatan untuk menilai sejauhmana keberhasilannya dalam belajar menulis Aksara Bali. Dengan demikian, kekurangan yang siswa miliki dalam belajar Aksara Bali menjadi pemicu untuk belajar secara mandiri untuk meminimalisis kekurangannya.

Dalam penilaian portofolio lebih mengutamakan proses, namun juga tidak mengesmpingkan hasil tes dari siswa. Semua itu merupakan satu kesatuan yang menjadi pertimbangan dalam memberikan nilai. Jika prosesnya bagus, maka secara otomatis hasinya bagus.

Dengan penerapan asesmen portofolio dalam pembelajaran menulis Aksara Bali, kemandirian siswa dalam belajar mulai nampak. Siswa mulai rajin membaca-baca buku berkasara Bali di perpustakaan. Siswa menjadi aktif dalam bertanya jika materi yang dijelaskan belum dipahami. Siswa juga bersemangat untuk menjawab pertanyaan yang dikemukakan baik oleh temannya maupun dari guru.

Pada kelas kontrol, guru menggunakan asesmen uraian dalam melakukan penilaian. Bentuk soal yang diberikan hanya tes menulis kalimat dengan Aksara Bali. Kriteria penilaian yang dilakukan guru tidak disampaikan kepada siswa. Siswa hanya menrima hasil berup skor dari guru tanpa mengetahui dimana letak kesalahannya. Jadi siswa tidak akan dapat mengetahui benar salahnya jawaban mereka. Hal ini menyebabkan kemandirian siswa dalam belajar menulis Aksara Bali kecil.

Hal ini juga didukung oleh hasil penelitian yang dilakukan oleh Chairunisa (2017) yang berjudul "Pemanfaatan Penilian Portofolio pada Mata Kuliah Evaluasi Pembelajaran Sejarah dalam Upaya Membangun Karakter Belajar mandiri dan Berkelanjutan". Hasil penelitian ini menunjukkan bahwa asesmen portofolio mampu membangun karakter belajar mandiri mahasiswa. Hal ini sejalan dengan hasil penelitian yang peneliti lakukan yang membuktikan bahwa asesmen portofolio mampu mempengaruhi kemandirian siswa dalam belajar menulis Aksara Bali.

Penelitian lain yang mendukung hasil penelitian yang peneliti lakukan adalah penelitian yang dilakukan oleh Ardana (2010) yangberjudul "Pengaruh Penerapan Pembelajaran Berbasis Peta Konsep tehadap Prestasi Kimia ditinjau dai Sikap Kemandirian (Studi Eksperimen pada Siswa Kelas X SMA Negeri 1 Nusa Penida). Hasil penelitian ini menunjukkan untuk siswa yang memiliki sikap kemandirian tinggi, hasil belajar kimia siswa yang mengikuti pembelajaran berbasis peta konsep berbeda secara signifikan dengan hasil belajar siswa yang mengikuti model pembelajaran langsung. Untuk siswa yang memiliki sikap kemandirian rendah, hasil belajar kimia siswa yang mengikuti pembelajaran berbasis peta konsep berbeda secara signifikan dengan hasil belajar siswa yang mengikuti model pembelajaran langsung. Terdapat pengaruh interaksi yang signifikan antara pembelajaran dengan sikap kemandirian siswa terhadap hasil belajar kimia. Hasil ini sejalan dengan hasil penelitian yang peneliti lakukan. Siswa yang mengikuti pembelajaran dengan asesmen portofolio memiliki kemandirian lebih tinggi dan nilai lebih tinggi dari siswa yang 
mengikuti pembelajaran dengan asesmen formatif bentuk uraian.

Berdasarkan uraian di atas, dapat disimpulkan bahwa terdapat perbedaan kemandirian menulis Aksara Bali antara siswa yang mengikuti pembelajaran dengan asesmen portofolio dengan siswa yang mengikuti pembelajaran menulis Aksara Bali dengan asesmen uraian. Siswa yang mengikuti pembelajaran menulis Aksara Bali dengan asesmen portofolio (kelas eksperimen) memiliki kemandirian menulis Aksara Bali lebih tinggi dari siswa yang mengikuti pembelajaran menulis Aksara Bali dengan asesmen uraian (kelas kontrol). Melihat kemandirian menulis Aksara Bali siswa yang mengikuti pembelajaran dengan asesmen portofolio lebih tinggi, maka asesmen portofolio layak dipilih maupun digunakan sebagai asesmen dalam pembelajaran menulis Aksara Bali.

Berdasarkan hasil uji hipotesis yang ketiga, diperoleh hasil bahwa terdapat perbedaan minat menulis Aksara Bali antara siswa yang mengikuti pembelajaran dengan asesmen portofolio dan siswa yang mengikuti pembelajaran dengan asesmen formatif bentuk uraian.

Pada kelas esksperimen, diperoleh skor minat menulis Aksra Bali sebanyak $37,5 \%$ siswa memperoleh skor sekitar ratarata, sebanyak $37,5 \%$ siswa memperoleh skor dibawah rata-rata, dan $25 \%$ siswa memperoleh skor di atas rata-rata. Pada kelas kontrol, diperoleh skor minat menulis Aksara Bali sebanyak 27,5\% siswa memperoleh skor sekitar rata-rata, sebanyak $60 \%$ siswa memperoleh skor dibawah ratarata, dan $12,5 \%$ siswa memperoleh skor di atas rata-rata.

Perolehan persentase skor tersebut menunjukkan bahwa minat menulis Aksara Bali pada kelas eksperimen lebih tinggi dari kelas kontrol. Persentase selisih skor sekitar rata-rata $10 \%$, selisih skor dibawah rata-rata $22,5 \%$, dan selisih skor di atas rata-rata $12,5 \%$.

Penilaian dalam kelompok eksperimen menggunakan asesmen portofolio, dimana menurut Dantes (2008); Marhaeni (2005) dalam penerapan asesmen portofolio selalu tiga elemen pokok yaitu: (1) sampel karya siswa, (2) kriteria penilaian yang jelas dan terbuka, dan (3) evaluasi diri.
Ketiga elemen pokok ini menjadi satu kesatuan yang tidak dapat dipisahkan dalam penerapan asesmen portofolio.

Sampel karya siswa merupakan elemen yang sangat penting dalam penialian, khususnya penilian portofolio. Dengan adanya sampel karya siswa, maka siswa akan mengetahui bagaimana perkembangannya dalam belajar menulis Aksara Bali dari awal sampai akhir. Segala sesuatu yang siswa kerjakan terekam dalam sampel karya siswa. Siswa tidak akan merasa dibohongi dalam penilaian karena mereka bisa melihat sendiri pekembangannya dalam belajar. Inilah yang memicu minat siswa untuk belajar menulis Aksara Bali.

Kriteria penilian yang jelas sangat dibutuhkan dalam melakukan sebuah penilaian. Dengan adanya kriteria penilaian yang jelas mereka tahu bagaimana sistem dan kriteria guru dalam menilai pada pembelajaran menulis Aksara Bali. Dengan demikian, siswa sangat tertarik untuk belajar menulis Aksara Bali. Siswa lebih senang dan antusias dalam mengikuti pembelajaran menulis Aksara Bali ketika mereka tahu kriteria penilannya.

Evaluasi diri merupkan elemen yang tidak kalah penting dalam penilaian asesmen portofolio. Siswa secara mandiri harus menilai kekurangan dan kelebihannya dalam belajar menulis Aksara Bali. Melalui evaluasi diri ini, minat siswa dalam belajar menulis Aksara Bali semakin tumbuh. Mereka diberikan kesempatan untuk menilai sejauhmana keberhasilannya dalam belajar menulis Aksara Bali. Dengan demikian, kekurangan yang siswa miliki dalam belajar Aksara Bali memicu keinginan siswa belajar.

Dalam penilaian portofolio lebih mengutamakan proses, namun juga tidak mengesampingkan hasil tes dari siswa. Semua itu merupakan satu kesatuan yang menjadi pertimbangan dalam memberikan nilai. Jika prosesnya bagus, maka secara otomatis hasinya bagus. Dengan penerapan asesmen portofolio dalam pembelajaran menulis Aksara Bali, minat siswa dalam belajar menulis Aksara Bali mulai nampak. Siswa antusias dalam mengikuti pembelajaran menulis Aksara Bali. siswa juga merasa senang dalam mengikuti pembelajaran menulis Aksara Bali. 
Ketertarikan menulis Aksara Bali terlihat dari konsentrasi dan kesungguhan siswa dalam mengerjkan tugas-tugas. Maka dari itu, minat menulis Aksara Bali siswa pada kelas eksperimen sangat tinggi.

Pada kelas kontrol, guru menggunakan asesmen uraian dalam melakukan penilaian. Bentuk soal yang diberikan hanya tes menulis kalimat dengan Aksara Bali. Kriteria penilaian yang dilakukan guru tidak disampaikan kepada siswa. Siswa hanya menrima hasil berup skor dari guru tanpa mengetahui dimana letak kesalahannya. Jadi siswa tidak akan dapat mengetahui benar salahnya jawaban mereka. Hal ini menyebabkan minat siswa dalam belajar menulis Aksara Bali lebih rendh dari kelas eksperimen. Siswa cenderung enggan untuk mengikuti pembelajaran menulis Aksara Bli. Mereka sering bermain-main saat mengikuti pembelajaran menulis Aksara Bali.

Hal ini diperkuat oleh hasil penelitian yang dilakukan oleh Agus (2013) yang berjudul "Pengaruh Optimalisasi Asesmen Diri terhadapa Kemampuan Menulis Bahasa Inggris ditinjau dari minat Siswa pada Kelas V di Gugus II Kecamatan Gianyar". Hasil penelitiannya menunjukkan adanya pengaruh interaksi antara jenis asesmen dan minat siswa terhadap kemampuan menulis Bahasa Inggris. Hasil penelitian ini menunjukkan bahwa asesmen dan minat memiliki adanya interaksi, dalam hal ini adalah asesmen portofolio dengan minat menulis Aksara Bali siswa.

Penelitian yang dilakukan oleh Dian (2011) berjudul "Pengaruh Implementasi Asesmen Portofolio terhadap Kemampuan Menulis Bahasa Inggris ditinjau dari Kecemasan Siswa (Studi Eksperimen pada Siswa Kelas VII SMP Negeri 1 Tabanan Tahun Ajaran 2010/2011)". Hasil penelitian tersebut menyatakan bahwa penerapan asesmen portofolio dan kecemasan siswa berpengaruh terhadap kemampuan menulis bahasa Inggris siswa kelas VII SMP Negeri 1 Tabanan tahun ajaran 2010/2011. Hasil penelitian ini sejalan dengan hasil penelitian yang peneliti lakukan, yaitu asesmen portofolio mempengaruhi minat menulis Aksara Bali siswa yang secara otomatis meningkatkan hasil belajar siswa. Minat siswa yang mengikuti pembelajaran dengan asesmen portofolio lebih tinggi dari minat siswa yang mengikuti pembelajaran dengan asesmen formatif bentuk uraian begitu juga dengan nilai siswa.

Berdasarkan uraian di atas, dapat disimpulkan bahwa terdapat perbedaan minat menulis Aksara Bali antara siswa yang mengikuti pembelajaran dengan asesmen portofolio dengan siswa yang mengikuti pembelajaran menulis Aksara Bali dengan asesmen uraian. Siswa yang mengikuti pembelajaran menulis Aksara Bali dengan asesmen portofolio (kelas eksperimen) memiliki minat menulis Aksara Bali lebih tinggi dari siswa yang mengikuti pembelajaran menulis Aksara Bali dengan asesmen uraian (kelas kontrol). Melihat minat menulis Aksara Bali siswa yang mengikuti pembelajaran dengan asesmen portofolio lebih tinggi, maka asesmen portofolio layak dipilih maupun digunakan sebagai asesmen dalam pembelajaran menulis Aksara Bali.

\section{SIMPULAN}

Berdasarkan rumusan masalah, tujuan, dan pembahasan yang telah diuraikan maka secara umum dapat diambil kesimpulan yaitu, pertama terdapat perbedaan kemandirian dan minat menulis Aksara Bali antara siswa yang mengikuti pembelajaran formatif bentuk portofolio dan siswa yang mengikuti pembelajaran dengan asesmen formatif bentuk uraian, kedua terdapat perbedaan kemandirian menulis Aksara Bali antara siswa yang mengikuti pembelajaran formatif bentuk portofolio dan siswa yang mengikuti pembelajaran dengan asesmen formatif bentuk uraian, ketiga terdapat perbedaan minat menulis Aksara Bali antara siswa yang mengikuti pembelajaran formatif bentuk portofolio dan siswa yang mengikuti pembelajaran dengan asesmen formatif bentuk uraian.

Berdasarkan simpulan di atas, dapat disampaikan beberapa saran sebagai berikut. Pertama, bagi guru khususnya guru mata pelajaran Bahasa Bali di tingkat SMP, asesmen portofolio dapat dipilih sebagai salah satu alternatif penilaian dalam pembelajaran menulis Aksara Bali. Asesmen portofolio sudah terbukti berpengarh positif terhadap minat dan kemandirian siswa dalam menulis Aksara Bali. Kedua, bagi 
siswa, dalam belajar menulis Aksara Bali perlu ditumbuhkan kemandirian dan minat belajar. Peningkatan kemandirian dan minat menulis Aksara Bali siswa bisa dirangsang oleh guru dengan menerapkan asesmen portofolio. Asesmen portofolio telah terbukti mampu meningkatkan kemandirian dan minat siswa dalam menulis Aksara Bali. Ketiga, bagi LPTK, hendaknya mengembangkan asesmen portofolio untuk diupayakan dan atau diajarkan pada mahasiswa sebagai calon tenaga pendidik, karena asesmen portofolio sudah terbukti mampu meningkatkan kemandirian dan minat siswa dalam belajar menulis Aksara Bali. Keempat, penelititan ini masih sangat terbatas hanya pada penerapan asesmen portofolio terhadap kemandirian dan minat menulis Aksara Bali. Apabila para pembaca tertarik melakukan penelitian lebih lanjut dapat melanjutkan penelitian ini dengan menambah variabel-variabelnya.

\section{DAFTAR PUSTAKA}

Agus, Seputra I Ketut. 2013. "Pengaruh Optimalisasi Asesmen Diri terhadap Kemampuan Menuis Bahasa Inggris ditinjau dari Minat Siswa pada Siswa Kelas V di Gugus II Kecamatan Gianyar". Tesis

http://pasca.undiksha.ac.id/ejourn al/index.php/jurnal ep/article/view 1695 (diakses pada tanggal 15 Januari 2018).

Ahmadi dan Uhbiyati. 1990. IImu Pendidikan. Jakarta: Rineka Cipta

Ardana, I Kadek. 2010 "Pengaruh Penerapan Pembelajaran Berbasis Peta Konsep tehadap Prestasi Kimia ditinjau dai Sikap Kemandirian (Studi Eksperimen pada Siswa Kelas X SMA Negeri 1 Nusa Penida). Tesis. http://pasca.undiksha.ac.id/ejournal/index.php/jurnal ep/article /view/68 (diakses pada tanggal 15 Januari 2018).

Arifin, Z. 2010. "Penilaian Portofolio (Konsep-prinsip-Prosedur)".
Makalah. Universitas Pendidikan Indonesia. Bandung

Chairunisa, Eva Dina. 2017. "Pemanfaatan Penilaian Portofolio pada Mata Kuliah Pembelajaran Sejarah dalam Upaya Membangun Karakter Belajar Mandiri dan Berkelanjutan". Tesis. http://www.univpgripalembang.ac. id/e jurnal/index.php/prosiding/art icle/view/1270/1107 (diakses tanggal 15 januari 2018)

Dantes, Nyoman. 2008. "Hakikat Asesmen Otentik Sebagai Penilaian Proses Dan Produk Dalam Pembelajaran Yang Berbasis Kompetensi". Makalah disampaikan pada In House Training (IHT) SMA N Kuta Utara, 2008

Dian, Wijayanti Kadek. 2011. "Pengaruh Implementasi Asesmen Portofolio terhadap Kemampuan Menulis Bahasa Inggris ditinjau dari Kecemasan Siswa (Studi Eksperimen pada Siswa Kelas VII SMP Negeri 1 Tabanan Tahun Ajaran 2010/2011)". Tesils. http://pasca.undiksha.ac.id/ejournal/index.php/jurnal pendas/a rticle/view/45 (diakses pada tanggal 16 Januari 2018)

Marhaeni, AAIN, 2005. "Pengaruh Asesmen Portofolio Dan Motivasi Berprestasi Dalam Belajar Bahasa Inggris Terhadap Kemampuan Menulis Bahasa Inggris (Study Eksperimen pada mahasiswa jurusan pendidikan bahasa inggris IKIP Singaraja)". Disertasi (tidak diterbitkan). Jakarta : Program Pascasarjana IKIP Negeri Jakarta.

Marhaeni, A.A.I.N. 2011..Asesmen Berbasis Kelas di Pendidikan Dasar. Program Pascasarjana Universitas Pendidikan Ganesha

Slameto. 2003. Belajar dan Faktor-Faktor yang Mempengaruhinya. Jakarta: Rineka Cipta.

Winkel, W. 1999. Psikologi Pengajaran. Jakarta: Grasindo. 